Revue d'histoire du XIXe siècle

Société d'histoire de la révolution de 1848 et des

révolutions du XIXe siècle

$5 \mid 1989$

Histoires de centenaires, ou le devenir des révolutions

\title{
La commémoration du centenaire de l'abolition de l'esclavage dans les colonies françaises, 1848-1948
}

\section{Nelly Schmidt}

\section{OpenEdition \\ Journals}

Electronic version

URL: http://journals.openedition.org/rh19/35

DOI: $10.4000 /$ rh 19.35

ISSN: $1777-5329$

\section{Publisher}

La Société de 1848

\section{Printed version}

Date of publication: 1 June 1989

ISSN: 1265-1354

\section{Electronic reference}

Nelly Schmidt, « La commémoration du centenaire de l'abolition de l'esclavage dans les colonies françaises, 1848-1948 », Revue d'histoire du XIXe siècle [Online], 5 | 1989, Online since 09 September 2008, connection on 03 May 2019. URL : http://journals.openedition.org/rh19/35; DOI : 10.4000/ rh19.35

This text was automatically generated on 3 May 2019.

Tous droits réservés 


\section{La commémoration du centenaire de l'abolition de l'esclavage dans les colonies françaises, 1848-1948}

Nelly Schmidt

\section{ABSTRACTS}

No abstract available by now

Pas de résumé disponible actuellement

INDEX

Mots-clés: Esclavage, Commémoration, Colonies 